RÉVÉSZ, Éva

\title{
CONTENT AND DRIVERS OF PERFORMANCE MANAGEMENT IN AGENCYTYPE ORGANIZATIONS OF THE HUNGARIAN PUBLIC ADMINISTRATION
}

The improving performance of public administration and the reform of public financing system have been on agenda in Hungary for many years, in accordance with the international trends. However, governments have not expected and supported creating of a performance-oriented public administration in a comprehensive and explicit way. Nevertheless, there are bottom-up initiatives at organizational level, which target performance-oriented organizational function.

The research focuses on organizations of central public administration where the successful application of performance management methods is most likely based on the international literature. These are the so called agency-type organizations, which are in Hungary called autonomous state-administration organizations independent of the Government (e.g. Hungarian Competition Authority), government bureaus (e.g. Hungarian Central Statistical Office), and central offices subordinated to the government (either the cabinet or a ministry) (e.g. Hungarian Meteorological Service). The studied agencies are legally independent organizations with managerial autonomy based on public law.

The purpose of this study is to get an overview on organizational level performance management tools applied by Hungarian agencies, and to reveal the reasons and drivers of the application of these tools. The empirical research is based on a mixed methods approach which combines both quantitative methods and qualitative procedures. The first - quantitative - phase of the author's research was content analysis of homepages of the studied organizations. As a results she got information about all agencies and their practice related to some performance management tools. The second - qualitative - phase was based on semi-structured face-to-face interviews with some senior managers of agencies. The author selected the interviewees based on the results of the first phase, the relatively strong performance orientation was an important selection criteria.

\section{Keywords: performance management, public administration, mixed methods research}

The improving performance of public administration and the reform of public financing system have been on agenda in Hungary for many years, in accordance with the international trends (Bouckaert - Halligan, 2008). However, governments have not expected and supported the creation of performance-oriented public administration in a comprehensive and explicit way. Nevertheless, there are bottom-up initiatives at organizational level, which target performance-oriented organizational function.

From a theoretical point of view, this situation is exciting contrary to the countries taking a leading role in performance management reforms in the public sector.
It represents a terrain where there are no comprehensive expectations set by the central government towards public administration regarding the content or the way of performance management applications, however, these methods have already appeared in the examined organizations. This situation makes the study of the drivers and the barriers for the introduction of performance management applications easier, separated from the expectations expressed by the government, which, as the international experience shows, in many cases results only in formal adaptation.

The research focuses on the organizations of the central public administration where the successful ap- 
plication of performance management methods is most likely to be based on international literature. These are the so called agency-type organizations (OECD, 2002; Verhoest, Van Thiel, Bouckaert, - Laegreid, 2012), which are called autonomous state-administration organizations in Hungary, independent of the Government (e.g. Hungarian Competition Authority), government bureaus (e.g. Hungarian Central Statistical Office), and central offices subordinated to the government - either the cabinet or a ministry (e.g. Hungarian Meteorological Service). The examined agencies are legally independent organizations with managerial autonomy based on public law. The number of this type of organizations was 75 in the beginning of 2015.

The purpose of this study is on the one hand to get an overview on organizational level performance management tools applied by Hungarian agencies, on the other hand to reveal the reasons and drivers of the application of these tools. The empirical research is based on a mixed research approach, which combines both quantitative and qualitative methods. The research structure has an explanatory sequential design, where the two phases of the research follow each other and first comes the quantitative phase. This phase of the research was a web content analysis of homepages of the Hungarian agencies, and the second part of the research was built on grounded theory and data was generated via semi-structured interviews with top managers of selected agencies.

\section{Performance management in the public sector}

Performance-oriented function is a goal that plays an important role in the reforms of public administration taking place today (Mol - de Kruijf, 2004; Pollitt - Bouckaert, 2011). In a broad sense performance management means the application of different management methods in order to increase the performance (economy, efficiency, effectiveness, equity) of a single organization or a network of organizations (e.g. a region, a sector, or a country). A possible critique against using the term of ,performance management” that it is an umbrella term, encompasses many different concepts, and its meaning is too board.

The exact determination of this research field makes difficult, that performance management is a buzzword both in business and public sector, and there are no common (and exact) definition in the literature (Franco-Santos et al., 2004). The main reason of conceptual uncertainty is that performance management is a multidisciplinary research field, it can be interpreted based on many scientific field. This statement is even more true to performance management in public administration, where jurisprudence (administrative law), political science, sociology and some fields of business administration have had also a great impact on today's thinking about performance management.

The intention of integrating various theories and approaches dealing with the same phenomenon - i.e. interpretation, measurement and management of public performance - appeared in the literature in the 90's, particulary among the academics of public management. In this regard the contribution of researchers of Public Management Institute at Catholic University of Leuven (http://soc.kuleuven.be/io/eng/) to formulation a theoretical framework of performance management in public sector is significant. Figure 1 shows the performance of an organisation or programme embedded in the socio-economic context. Performance management is shown as a management (or regulation) cycle, i.e. it follows the cyclical logic scheme of goal-setting and planning, measurement and feed-back - evaluation.

Figure 1

Performance management in the public sector (based on Van Dooren, Bouckaert - Halligan, 2010

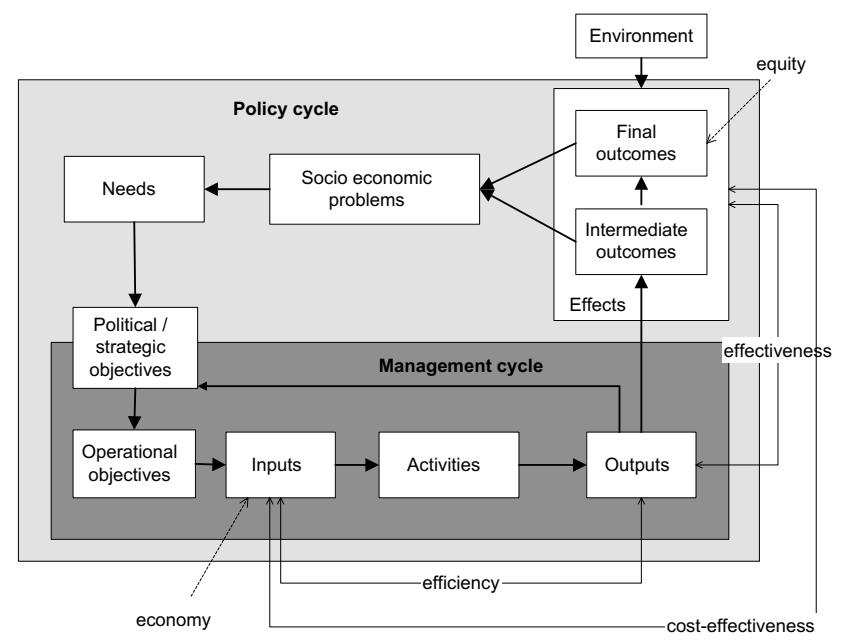

The performance management concept of the public sector (Wouter Van Dooren - Bouckaert - Halligan, 2010) can be divided into two different levels: the level of public policy (policy cycle) and the level of management (management cycle). This study concentrates on the management cycle: the concept, the characteristics and the tools of organizational-level performance management.

\section{Performance management at organizational level in the Hungarian public administration}

The performance and performance management of public administration (and the public sector) are com- 
plex concepts that are often difficult to operationalize (Takács, 2015). Therefore, it is important to outline the concepts of possible content components and interrelations, which might be found in Hungarian administrative organizations. By this I do not intend to design a normative model but to list the components which embody and support performance orientation in the central organizations of the Hungarian public administration. Various constellations and patterns of these components are possible. Several subcomponents might appear as an integral and comprehensive performance management system; however, it is more likely that even if certain elements of performance management appear in the practices of the examined organizations, these are rather isolated innovative solutions and do not apply to the overall management cycle.

Organizational level performance management (PM) in its "mature form" is a system supporting and coordinating the management cycle, i.e. the cyclically repeated planning-measurement-feedback actions, providing the most important stakeholders with relevant information and attempting to improve efficiency, effectiveness and quality at every level of the organization (Bodnár, 2005). It does not appear as an independent subsystem within the organization, but it can be interpreted as a process resulting from the cooperation of several functional areas, among which direct and strong relationships can be established: the planning system defining the objectives, the finance and accounting system, management control systems, quality management, the human resources management system as well as the information system producing information (may) belong here. Its major functions may be:

- to support managerial decisions with relevant information,

- to support strategic planning,

- to communicate objectives and requirements within the organization,

- medium-term and operative (short-term) planning,

- to design and operate measurement systems (cost-calculation, performance and quality indicators),

- analysis and feedback on the achievement of objectives, and

- to design the motivation system for the improvement of performance.

In public administration, managers who are key players in decision-making may not only be the heads of the examined organizations but also the managers of the superior organization responsible for the decisions concerning the given organization and also politicians. Therefore, apart from the support of internal decisions, the support of external decisions may have an emphatic role in the public sector.

A possible representation of the performance management process interpreted within administrative organizations is displayed in the Figure 2.

Figure 2

\section{Performance management system at organizational level}

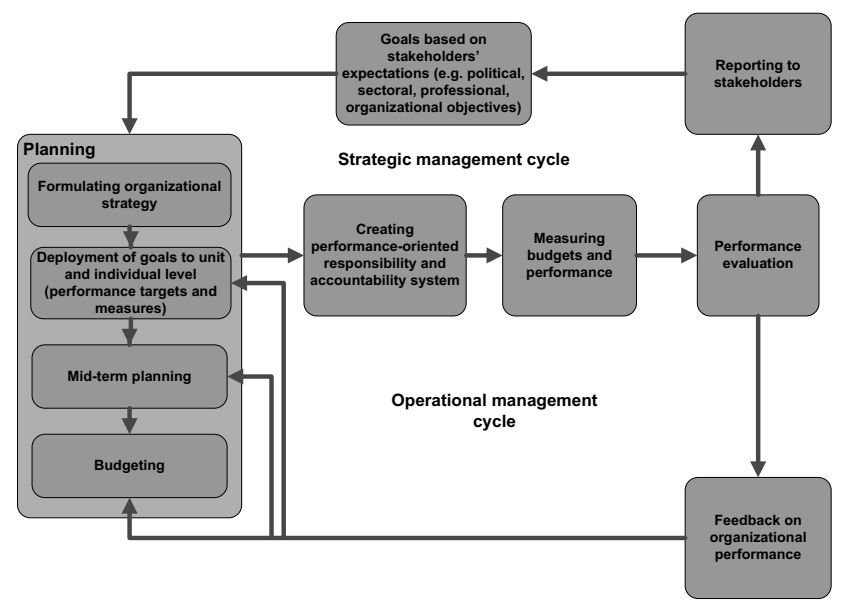

The strategic level of the performance management system helps to specify the long-term strategic objectives, usually defined in generic terms, as well as to communicate them within the entire organization. From a theoretical point of view, the relationship between the strategic and operative levels is established by the preparation of medium-term tactical plans derived from the strategic objectives. In Hungary the institutional budget provides the framework for the annual operation of budgetary institutions under the scope of the Public Finance Act. According to the applicable regulations, institutional budget planning does not starts from the strategic or medium-term objectives but is constituted characteristically on the basis of the previous year (with a few or more modifications of the budget numbers of the previous year).

The annual plan provides the basis for everyday operation and it is broken down into the levels of responsibility centres (organizational units, projects, programmes, see (Anthony - Young, 2003) and even organization members (e.g. MBO agreements). The interim changes of the accomplishment of the operative plan may be monitored by the performance measurement system (e.g. with appropriate cost calculation), which in turn - within the framework of performance evaluation (interim monitoring) - is interpreted by creating of various analyses for decision-makers. The feedback on the operative cycle provides information primarily on the interim use of resources and makes 
suggestions on the necessary interventions. The role of feedback within the strategic cycle is predominantly to help monitoring the achievement of strategic objectives, to draw attention to the unforeseen changes in time and to be able to the design potential recommendations for the changes of the plan.

Starting from the components of the strategic and operative management cycles (goal-setting and planning, measuring, feed-back-evaluation), a shift towards performance orientation within Hungarian public organizations is possible in the case of the following activities.

\section{Goal-setting and planning}

The planning of the annual budget embodies the planning activity of budgetary institutions of central administration. In 2012 a government decree on governmental strategic management was established (Government Decree 38/2012 (III. 12.) on Government Strategic Management), but the formulation organizational strategies is still not a compulsory, only a recommended activity.

The institutional budget is calculated on the basis of the previous year, and the expenses of the next calendar year are planned with respect to different types of costs (personnel expenses, material expenses, etc.). Thus, the planning is input-oriented and next year's budget is calculated on the basis of past activities, but it usually does not question the original figures. The planning activity is mechanical and instead of the entire organization, only the financial department participates in it.

This budgeting logic is suitable for national and sectoral framework planning, however, its organizational application (reverse planning) means that specialities and expected quality of the tasks to be accomplished are hardly if at all taken into account. This results, for instance, in that the need for the extension of fiscal framework is difficult to justify. The lack of clear goal-setting hinders feedback and evaluation.

Performance budgeting techniques offer an alternative to traditional input-oriented line item budgeting. A part of those is applicable at organizational level even if macro-economical budgeting takes place in the traditional (line item and input-oriented) way. Some examples of these tools include but are not limited to the following:

- instead of the previous year the overview of tasks to be accomplished and the measurement of their financing needs considered as a starting point,

- the definition of performance objectives at different levels of programmes and organizational units as well as indicators attributed to these,

- multi-year (business) planning, strategic planning.

Performance-oriented planning requires profound methodological-professional expertise and implies several difficulties. Different works discussing the selection of unsuitable goals and indicators as well as the dangers of manipulation represent a large segment of the literature on performance management in the public sector (de Bruijn, 2002; Hood, 2006).

\section{Accounting and measurement}

Planning is followed by the continuous monitoring of operation as well as the measuring of performance in the management cycle. In the Hungarian public finance organizations the requirements of budgetary accounting are to be followed. The structure of budget accounting is much more determined by the need for budget planning than by the support of the management decisions of individual organizations.

Hungarian budget accounting meant a so-called modified cash-based double-entry bookkeeping till the beginning of 2014. From cash-based perspective, transactions appear in the accounts simultaneously with the cash flow, i.e. payments and incomes are recorded. The accounting practices of Hungarian budgeting have implied numerous problems, the main reason for which is that the system focuses on the cash flows of the budgetary year. Some of the arising problems are related to the fact that certain information needs cannot be satisfied due to the way of accounting, while other problems are in connection with the fact that the accounting system - with respect to long-term economy - is unfavourably influencing the decision-makers.

Due to the above-mentioned reasons the introduction of accrual accounting in the beginning of 2014 has been a great opportunity and a significant change in the Hungarian public administration (Government Decree 4/2013 (I. 11.) on the Accounting of Public Finances). Since the regulation on accrual accounting is rather fresh, it is too early to evaluate its results after one calendar year. Anyway, it can be an important step towards performance-oriented operation.

The definition of performance requirements is unresolved and performance measurement based on financial and accounting data (the use and analysis of financial indicators) have no traditions in Hungarian public organizations.

\section{Feedback and evaluation}

The main goal of feedback (reporting) with respect to performance management is to call decision-makers' attention to the deviations from the plans, to contribute to the exploration of the reasons and also to provide an opportunity for intervention. Reporting may be related to individual performance appraisal as well, it serves as 
the basis for the evaluation of managerial performance. Thus, reporting does not merely mean the preparation of financial and accounting statements but it is also an important tool of supporting managerial decision-making.

As mentioned above, the analysis and the evaluation based on financial and other data supporting decision-making are infrequent in Hungarian public organizations. However, budgetary organizations are supposed to provide other institutions (superior organizations, the Central Statistical Office, the National Tax and Customs Administration, the State Treasury, etc.) with frequent and various data. According to Zsuzsa Kassó: "The remarkable colourfulness, overlaps and deficiencies which in practice arise [in relation to reporting obligations] are almost impossible to show. However, management should take into account that the institutional system invests a considerably large amount of money and energy in preparing reports and accounting data and indeed, plenty of information is produced. The content and the form of these, however, do not support decisions; it is very difficult to find data in this data set, produced with a lot of effort, which is really useable for the management" (Kassó, 2006, p. 83).

Performance reports produced for external stakeholders (politicians, citizens, superior organizations) could have a particularly significant role in administrative organizations, as they could be the means of enforcing transparency and accountability. Apart from input data, performance-oriented reports also include data about other dimensions of performance in a clearcut format.

Beside the content components, the extent of institutionalization and the integration of performance management elements to be analysed in the research may also offer interesting conclusions. By institutionalization I mean whether there is an organizational unit or job within the organization in which duties related to performance management are also represented among the tasks (e.g. management control department, quality department, etc.).

The analysis of integration refers to the fact whether the elements embodying performance-oriented organizational operation are connected to each other or not. The extent of integration can be examined among the partial organizational systems covering the functions mentioned above (e.g. accounting, quality management, IT) as well as among the different levels of the organization (organization-organizational unit-individual).

\section{Possible drivers of performance management applications}

In addition to the exploration of possible content components of administrative performance management, the article also examines the question what factors and mechanisms (drives) can be associated with the design and introduction of performance management applications. While a large number of publications have been released on the analysis of factors related to and explaining the performance improvement of public sector organizations (Boyne, 2003; W. Van Dooren - Lonti - Sterck - Bouckaert, 2007), a significantly smaller number of research has addressed the exploration of factors and mechanisms related to the application (design and implementation) of performance management tools in public sector. The amount of revealed evidence is low and the research results often contradict one another. This phenomenon is due to the fact that factors or mechanisms of similar names are operationalized in different ways and measured with different methods (Wouter Van Dooren, 2006; Van Helden - Johnsen Vakkuri, 2007).

\section{Main factors related to designing performance management in public administration}

\begin{tabular}{|l|c|c|c|}
\hline \multicolumn{1}{|c|}{ Contextual factors } & Cavaluzzo - Ittner & Van Dooren & $\begin{array}{c}\text { De Lancer Julnes - } \\
\text { Holzer }\end{array}$ \\
\hline $\begin{array}{l}\text { Existence of external compulsory performance require- } \\
\text { ments (e.g. performance indicators) }\end{array}$ & Not significant & & Significant \\
\hline Availability of resources & & Not significant & Significant \\
\hline Role of trainings & Significant & & Significant \\
\hline Management commitment & Significant & & \\
\hline Decision making authority & Significant & Not significant & Significant \\
\hline Goal or mission orientation & & Not significant & \\
\hline $\begin{array}{l}\text { Ability to identify and interpret performance indicators } \\
- \text { measurability of performance }\end{array}$ & Significant & Significant & \\
\hline Internal interest groups & & & Significant \\
\hline Size of organization & & Significant & \\
\hline
\end{tabular}


The Table 1 summarizes the results of three researches. An article of Patria De Lancer Julnes and Marc Holzer published in 2001 was based on the analysis of a survey of 1997, for which data was retrieved in the United States at local, national and federal government agencies by interviewing their staff (Julnes - Holzer, 2001). Ken S. Cavaluzzo and Christopher D. Ittner analysed the results of a survey of organizations of the federal government, conducted similarly in the USA in the year 1997 (Cavalluzzo - Ittner, 2004). Van Dooren was carrying out research in public organizations in Belgium between 2000-2005 (Wouter Van Dooren, 2005). While in the above-mentioned two researches results were obtained based on multivariate statistical analysis of the questionnaires, Van Dooren used, in addition, some other methods such as content analysis, semi-structured and unstructured interviews.

By examining the table, it is conspicuous that although the same factor occurs in several studies, but its relation with the design of performance management tools is considered differently. There are two exceptions to this rule: the importance of the role of training and the ability to identify and interpret performance indicators, and the importance of measurability of the performance is clearly confirmed in each research.

The reason for conflicting results have already been mentioned: the presented researches have operationalized, measured, analysed the above-mentioned factors differently. In addition, the design of performance management, which was considered as a dependent variable, was defined differently in the researches.

The contradictions in the research results indicate that, firstly, it is a 'bumpy' field of study, and, secondly, these contradictions raise exciting and innovative research questions. The above-mentioned surveys and their results, despite all of their shortcomings, give clues which factors and mechanisms should be examined in this research. The Table 2 summarizes the potential factors and mechanisms, which presumably are related to the use of performance management tools.

Two factors in the table above may require more detailed explanation: public interest towards the organization has a number of reasons (Moynihan - Pandey, 2005). On the one hand, a public administration organization can dispose over a large budget, and that fact alone can already be significant to the public; on the other hand, administrative organizations operating in socially sensitive areas (e.g. healthcare) might also be in the centre of attention.

Some studies categorize resources as external, some as internal factors. This can either mean the cumbersome use of the external-internal dichotomy and its questionability, or may also refer to definitional discrepancies. I regard organizational resources as both internal and external factors: internal because it is about assigning organizational resources or it can be considered as external factor, the question in this latter case is whether such obtainable resources (e.g. grants) exist that support the development of performance management tools.

Possible factors and mechanism related to formulating performance management tools

Table 2

\begin{tabular}{|l|l|}
\hline Factors & Short interpretation \\
\hline $\begin{array}{l}\text { Public interest towards the orga- } \\
\text { nization }\end{array}$ & Due to budget size or handling of socially sensitive field \\
\hline $\begin{array}{l}\text { Expectations of superior organi- } \\
\text { zations }\end{array}$ & They could be public administration or political organizations \\
\hline $\begin{array}{l}\text { International organizations and } \\
\text { patterns }\end{array}$ & $\begin{array}{l}\text { International centres of policy transfer (European Commission, OECD), or } \\
\text { partner organizations in the world (e.g. tax authorities worldwide) }\end{array}$ \\
\hline Role of management consultants & Methodological experts of performance management tools and models \\
\hline Access to external resources & External resources supporting performance management \\
\hline $\begin{array}{l}\text { Measurability of organizational } \\
\text { activities }\end{array}$ & Easy / difficult identification of performance measures \\
\hline Training & Professional and methodological knowledge transfer \\
\hline Commitment of top management & Support and expectations towards performance management \\
\hline Goal orientation & Focus on results, long-term strategies \\
\hline Available internal resources & $\begin{array}{l}\text { Assigning of financial, human and ICT resources to performance manage- } \\
\text { ment }\end{array}$ \\
\hline
\end{tabular}




\section{Agency-type organizations in Hungary}

One of the key features of New Public Management movement is the so-called 'agencification" phenomenon analysed by numerous researches and publications (OECD, 2002; C. Pollitt - Talbot, 2004; Wettenhall, 2005). This means formulating organizations that 'operate at arm's length of the government to carry out public tasks, implement policies, regulate markets and policy sectors, or deliver public services'. They are structurally disaggregated from their parent ministries, are said to face less hierarchical and political influences on their daily operation and have more managerial freedom in terms of finances and personnel, compared to ordinary ministries or departments" (Verhoest et al., 2012, p. 3.). Agency-type organizations exist in large numbers in countries which are not considered to be the forerunners of NPM, and therefore their establishment is not clearly linked to the principles of NPM - this is the case in Hungary as well (Hajnal, 2010).

In fact, there is no generally accepted definition in the international literature, and even terms can be quite diverse. They are called agencies, quasi-autonomous or semi-autonomous organizations, non-departmental public bodies, quangos, arms-length organizations etc. The diversity of definitions and terms is rooted in the heterogeneity of the examined organizations: from country to country a variety of characteristics can be found ranging from the different formal-legal solutions to various responsibilities and managerial autonomies.

In this research by "agency" I refer to legally independent public organizations directly subordinated to the government (either the cabinet or a ministry), having nationwide competences. Private or private-law based organizations established by the government are excluded, and the public organizations subordinated to the parliament are included.

In Hungary a rapidly evolving and heterogeneous organizational circle corresponds to the agency concept. The Table 3 summarizes the typology of agencies on their legal-structural features in 2015.

The number of these organizations has changed recently: while in the nineties there were $22-25$ main authorities, in the beginning of 2000 the number increased to 30 , around 2010 it was between 50-60 (Lőrincz, 2005). The number of this type of organizations was 75 in the beginning of 2015, when this research was conducted.

\section{Research design, questions and methodology}

The scope of this study is to examine the design (content) and implementation of the organizational level performance management tools in the Hungarian agencies along the following questions:

What kind of performance management tools appear in the "agency"-type organizations of the Hungarian public administration?

What drivers and mechanisms may explain the design and introduction of performance management tools in the examined organizations?

The empirical research is based on a mixed approach, which combines both quantitative and qualitative methods (Király - Dén-Nagy - Géring - Nagy, 2014). I have chosen an explanatory sequential research design (Creswell, 2009; Creswell - Plano Clark, 2011), which starts with the collection and analysis of quantitative data. The first phase is followed by the subsequent collection and analysis of qualitative data. The second, qualitative phase of the research is designed in a way that it is derived from the outputs of the first, quantitative phase. (Figure 3)

\section{Agency-type organizations in Hungary (based on Hajnal, 2011)}

\begin{tabular}{|l|l|l|l|l|}
\hline \multicolumn{1}{|c|}{ Features } & $\begin{array}{c}\text { Autonomous } \\
\text { administrative } \\
\text { organization }\end{array}$ & \multicolumn{1}{|c|}{$\begin{array}{l}\text { Independent regulatory } \\
\text { body }\end{array}$} & \multicolumn{1}{|c|}{$\begin{array}{l}\text { Governmental } \\
\text { bureau }\end{array}$} & \multicolumn{1}{|c|}{ Central bureau } \\
\hline Founder & Law & Law & Law & Government decree \\
\hline Superior organ & Parliament & Parliament / Cabinet & Cabinet & Ministry \\
\hline $\begin{array}{l}\text { Appointment } \\
\text { of agency head }\end{array}$ & Based on statute & $\begin{array}{l}\text { Appointed by the prime } \\
\text { minister or the president } \\
\text { of the republic based on } \\
\text { the proposal of the prime } \\
\text { minister }\end{array}$ & $\begin{array}{l}\text { Appointed by the } \\
\text { prime minister based } \\
\text { on the proposal of } \\
\text { the superior minister }\end{array}$ & $\begin{array}{l}\text { Appointed by the } \\
\text { superior minister }\end{array}$ \\
\hline Example & $\begin{array}{l}\text { Hungarian } \\
\text { Competition } \\
\text { Authority }\end{array}$ & $\begin{array}{l}\text { National Media and } \\
\text { Infocommunication } \\
\text { Authority }\end{array}$ & $\begin{array}{l}\text { Hungarian } \\
\text { Intellectual Property } \\
\text { Office }\end{array}$ & $\begin{array}{l}\text { National Health } \\
\text { Insurance Fund of } \\
\text { Hungary }\end{array}$ \\
\hline
\end{tabular}




\section{Explanatory sequential research design (Creswell, 2009)}
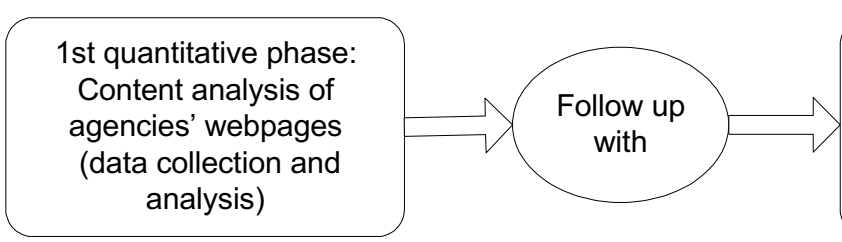

The first - quantitative - phase of the research was content analysis of homepages of the examined organizations. Content analysis is an appropriate method for arranging texts into a generalized coding structure, which can be easily transformed into a database. This method draws conclusions not only on the texts themselves (homepages) but also on their context (the organizations) (Krippendorff, 2004). The aim of the analysis is to reveal statistical descriptions, like frequencies, and connections, and significant differences between topics etc. (Figure 4)

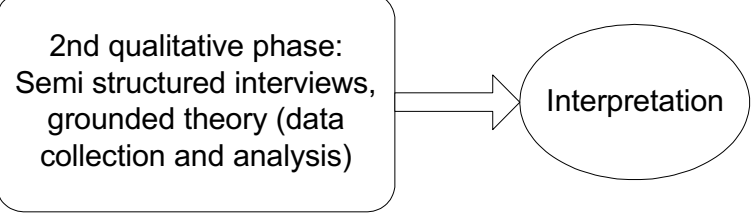

The second - qualitative - phase was based on semi-structured face-to-face interviews (Kvale, 2005) with some senior managers of agencies. The main focus of the qualitative phase was to answer the second research question (identifying drivers of applying performance management tools). The interviewees were selected based on the results of the first research phase: the relatively strong performance orientation was an important criteria. I was searching for organizations where multiple performance management tools were applied and performance management was to some ex-

\section{Process of web content analysis (1st phase of the research)}

Figure 4

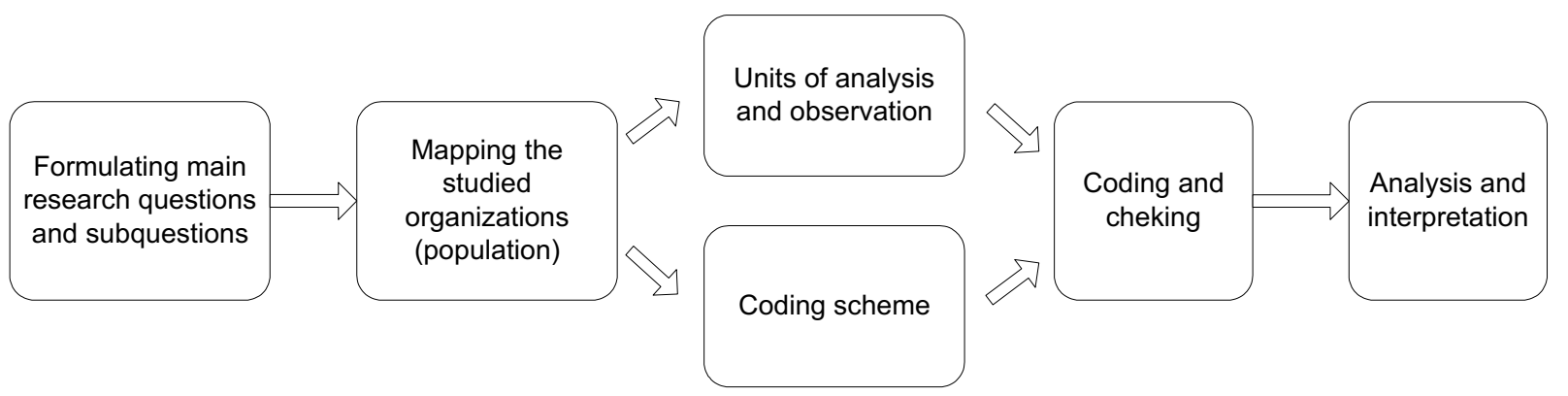

I identified some kinds of performance management content (e.g. mission statement, strategy, annual report) on agencies' homepages (see coding structure in Table 2) and analyzed significant differences of content between groups by the given organizational features (e.g. number of employees, revenue, international relations etc.). As a result, I have got information about all agencies and their practice related to some performance management tools.

It is critical to keep in mind that the information on websites do not give a full and accurate picture about actual organizational processes. However, the examination of content appearing on websites (the communication of the organization on Internet) provides an opportunity to draw conclusions about agencies' attitude towards performance management and the role and institutionalization of performance orientation. tent institutionalized. This was an important factor in selecting the interviewees because this means that they have some kind of experience and interpretation about the elements and conception of performance management and they may have an opinion about the factors supporting and hindering the application of performance management.

Web content analysis helped to identify also the focus points of the research. As a result of content analysis a few factors have emerged, which can have a relation with the application of performance management. Revealing these factors deeper and understanding the mechanisms have oriented the data collection and data analysis in the qualitative research phase.

In accordance with the grounded theory approach the course of interviews had been developed iteratively, i.e. first I started with open questions and later I asked about for example relationships of identified catego- 
ries as well (Esse, 2012; Mitev, 2012). Analysing these interviews one could reveal how various interviewees give different interpretations to a particular social phenomenon (like performance management in Hungarian agencies), and the most important characteristics of this method is the assumption that that participants (interviewees) build up the reality (Strauss - Corbin, 1998). (Figure 5)

Figure 5

The process of qualitative research (2nd phase)

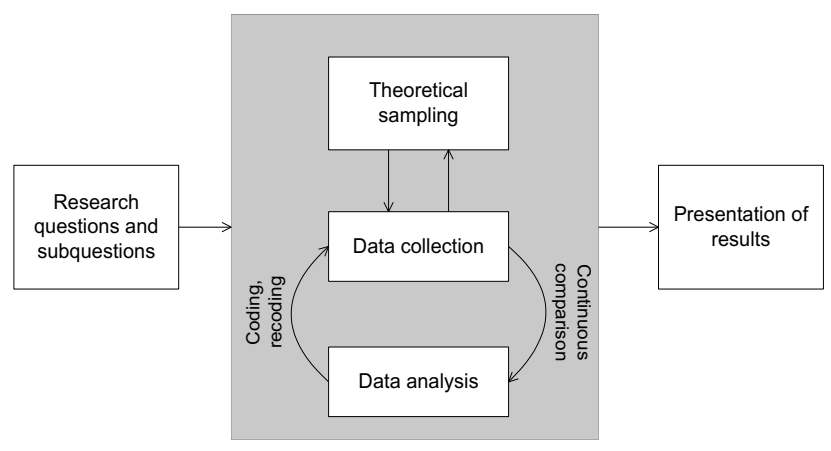

In grounded theory approach data collection and data analysis cannot be strictly separated, data analysis is carried out continuously also in the time of the new interviews, thus the outcomes of a previous interview can be built in the following interviews. The way of data analysis was coding. According to Strauss and Corbin (1998) this is a multi-level process, starting with open coding, then relationships, connections are being searched in the categories identified (axial coding), finally the evolving theory is being integrated, specified (selective coding). In the coding process I used the NVivo data analysis software.

\section{Results of the research}

During the web content analysis I have gained a comprehensive picture about the Hungarian agencies (their exact number, size, age, etc.). It is also an important result because there is no formal, official list or database of Hungarian agency-type organizations (Hajnal, 2012). First, I will briefly present some characteristics of the examined organizations, what helps to understand the context, in which the results of the data analysis are valid. At the time of the research 72 agencies (out of 75) had a homepage.

\section{Some features of Hungarian agencies}

The Figure 6 shows the governmental functions (COFOG, Classification of Functions of Government) of examined agencies. In organizations where more governmental functions appear at top level, I tried to identi- fy the dominant function. Most agencies operate in the area of economic affairs and general public services.

Agencies based on governmental functions

Figure 6

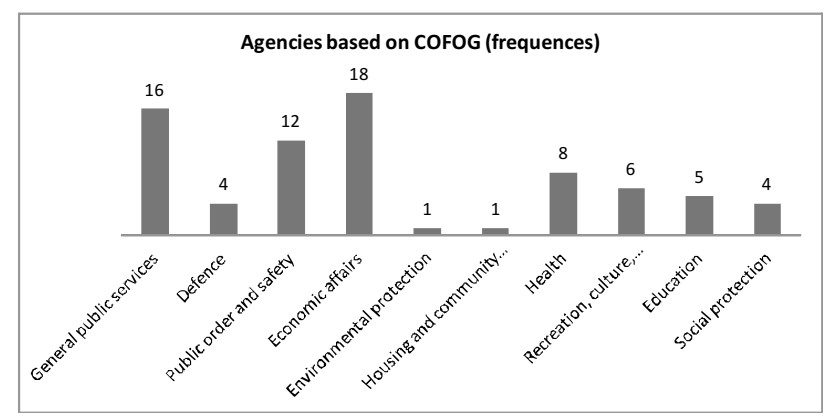

The smallest organization employed 20 people, while the largest 130.330 people at the time of data collection. The latter, however, is an extremely high number, only three agencies had more than $2000 \mathrm{em}$ ployees. The age of the examined organizations varies widely as well, the oldest agency was 145 years old and the youngest agency was established in the beginning of 2015. (Figure 6)

An important factor regarding the stability of organizations is the time since the head of agency has been appointed. The design and the introduction of performance management tools require relatively long time (several months), and due to the cyclical nature of PM systems their results come only 1-2 years following the introduction. The expectations and the support of top management of agencies are critical in this process.

The heads of examined agencies spent on average 3.2 years in their current position. I have found only six organizations where the head has been managing the agency for more than 5 years, i.e. he or she was in the current position before the change of the government in 2010 as well. However, in half of the organizations (34 cases) heads have changed also within the last two years - even several times. (Figure 7)

Figure 7

The age of agencies and the number of years since the appointment of the head

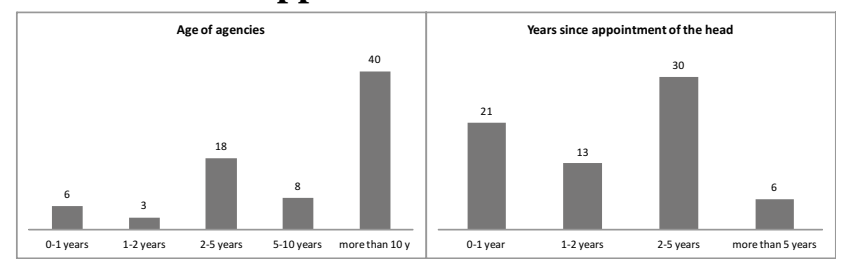




\section{Coding scheme related to performance management content}

\begin{tabular}{|l|l|l|}
\hline \multicolumn{1}{|c|}{ Main themes } & \multicolumn{1}{c|}{ Categories (codes) } & \multicolumn{1}{c|}{ Explanation } \\
\hline \multirow{5}{*}{ Planning } & Mission statement & Mission statement / values / vision of the agency \\
\cline { 2 - 3 } & Strategic plan & Strategic document of the agency \\
\cline { 2 - 3 } & Operational plan on the website & $\begin{array}{l}\text { Short-term professional-operational plan on the } \\
\text { web }\end{array}$ \\
\cline { 2 - 3 } & $\begin{array}{l}\text { Operational plan in organiza- } \\
\text { tional and operational rules } \\
\text { (OOR) }\end{array}$ & $\begin{array}{l}\text { Short-term professional plan in the organiza- } \\
\text { tional and operational rules (or charter) of an } \\
\text { agency }\end{array}$ \\
\cline { 2 - 3 } Reporting & Annual budget & Annual budget of the agency \\
\hline Report on budget & Report on the budget \\
\hline Quality management & $\begin{array}{l}\text { Pocuments of quality mana- } \\
\text { gement }\end{array}$ & Report on the agency's (annual) performance \\
\hline \multirow{2}{*}{$\begin{array}{l}\text { Institutionalization of per- } \\
\text { formance management }\end{array}$} & Management control & Organizational unit or position \\
\hline & Quality management & Organizational unit or position \\
\cline { 2 - 3 } & Strategy & Organizational unit or position \\
\hline
\end{tabular}

\section{Elements of PM systems in Hungarian agencies}

During the web content analysis only those elements of PM were examined which can be displayed on websites. The list is presented in Table 4.

It is important to note that the appearance of annual budget and budget report on the websites is not really related to performance management, because in Hungary budgeting is traditionally an input-oriented line item planning based on the previous year. The reason for examining these documents is that publishing budget information on the web increases transparency and therefore it is obligatory for each Hungarian public organization.

More than three-quarter of the examined agencies published the annual budgets and budget reports on the web. This rate cannot be assessed as high because based on regulation it is an obligatory task for all agencies.

According to organizational and operational rules (available also on the examined homepages) 55 agencies formulate annual operational plan, but only 16 organizations publish these on their websites. Formulating an annual operational plan is also an obligatory task for agencies. Nearly half of the agency-type organizations (34 cases) publishes a performance report regularly, typically on an annual basis and evaluates the professional work of the organization. 24 agencies published their mission statement on the Internet. The appearance of this topic is a sign of long-term planning,
Elements of PM on the websites of the agencies (frequencies, $\mathrm{N}=72$ )

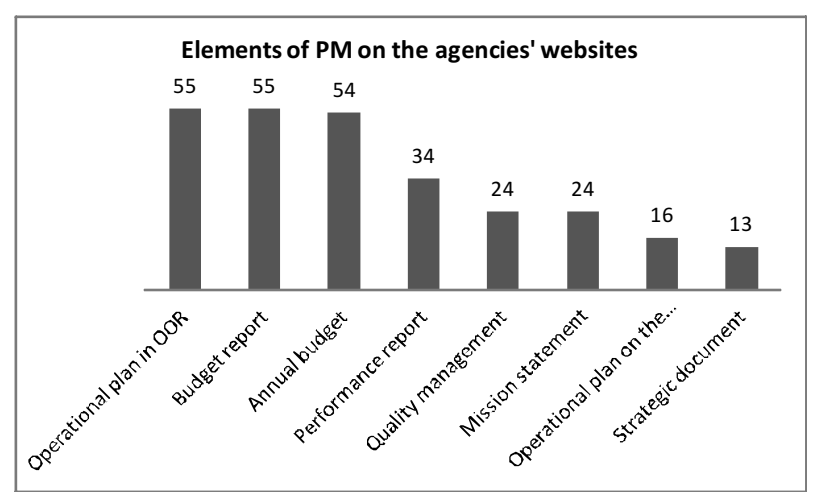

because formulating a mission statement is part of strategy development. I have found a strategic plan on the websites of the agencies in 13 cases. One third of the organizations publishes documents related to quality management, such as quality policy statement or ISO certificate. (Figure 8)

I examined how intense the use of different methods is, this has meant the calculation of total points of the following five categories: mission statement, strategic document, operational plan on the website, performance report, quality management. 
Figure 9 Intensity of the use of PM methods (frequencies)

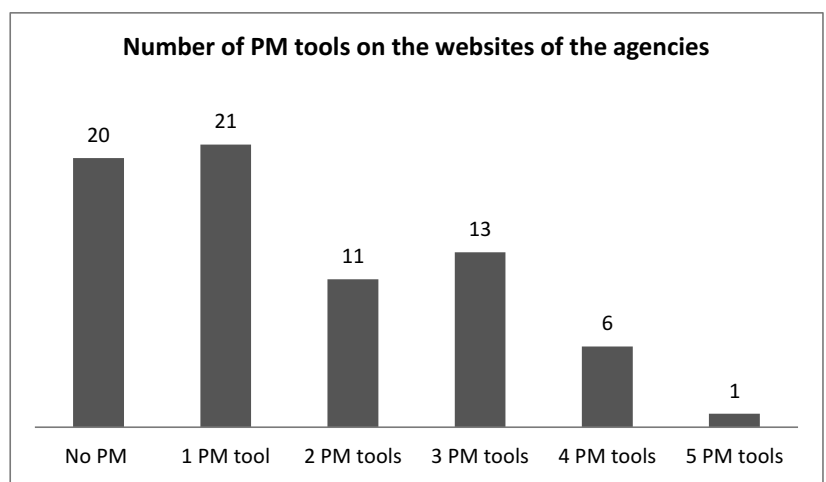

Three quarters of the agencies publish at least one performance management tool and more than 40 per cent (31 organizations) communicate the use of at least two types of performance management tools. Of course the appearance of a PM method in itself does not mean that performance oriented function does exist, but when more PM tools are being communicated, it is more likely that a PM system is operating in the given organization. (Figure 9)

The use of PM-related organizational units or positions represents the institutionalization of performance management. The figure below summarizes the main findings regarding the appearance of quality management, management control or strategic management units / positions in the examined agencies.

\section{PM-related organizational units or positions in Hungarian agencies}

PM related organizational units or positions in agencies

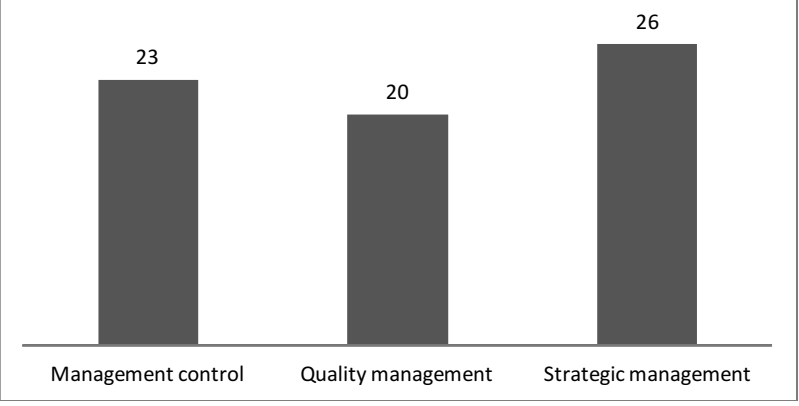

Strategic departments can be found in more than one third of the agencies, management control units or positions are operated in 23 organizations and departments or positions responsible for quality management exist in 20 agencies. The intensity of institutionalization shows how many PM-related departments or positions the organizational structure includes (see Figure 10). Approximately 40 per cent of agencies do not use the examined PM-related organizational units or position at all. In 21 organizations (30 per cent) I have found one type of department or position, in 18 agencies two examined areas were institutionalized, while four organizational structures contained all three areas.

\section{Intensity of PM institutionalization} (frequencies, $\mathrm{N}=70$ )

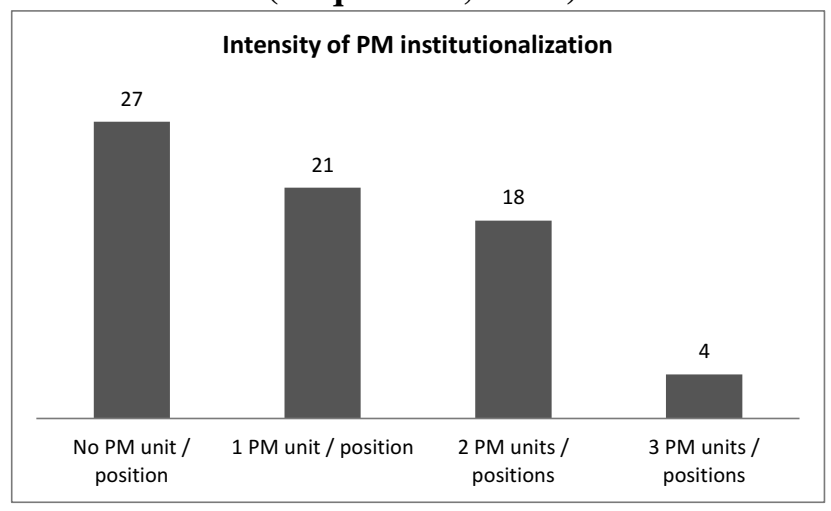

There is an existing and positive relation between these two variables (the correlation coefficient is 3.14, $\mathrm{p}=0.001$ ): organizations which publish multiple PM methods on the Internet have institutionalized this field to a higher extent, i.e they have more PM-related organizational units or positions. (Figure 11)

\section{Main results of qualitative research phase: drivers of PM in Hungary}

In this subchapter I will summarize the main findings of the qualitative research phase. During March-April 2015 I made 6 interviews with top managers and one interview with an expert (consultant). Interviewees were well-informed about of the potential areas where the different PM methods can be applied. Although in the selected organizations PM methods appeared with very different emphasis and roles, a series of PM tools have been applied everywhere and these agencies have PM-related organizational units as well. The relatively strong performance orientation was an important selection criteria of the interviewees.

The main results of the qualitative research phase are summarized in Figure 12 (see below), it is a system of main supporting and interfering factors influencing PM applications. Based on the grounded theory it is considered to be a middle-range substantive theory which might be taken to application only in the exam- 
ined specific area or context (Glaser - Strauss, 1967). Mechanisms and relations among categories were formulated during the coding and re-coding of the the interviews, and the first phase of the research have also had an impact on identifying some of the categories.

Figure 12

\section{The system of drivers and interfering factors influencing PM}

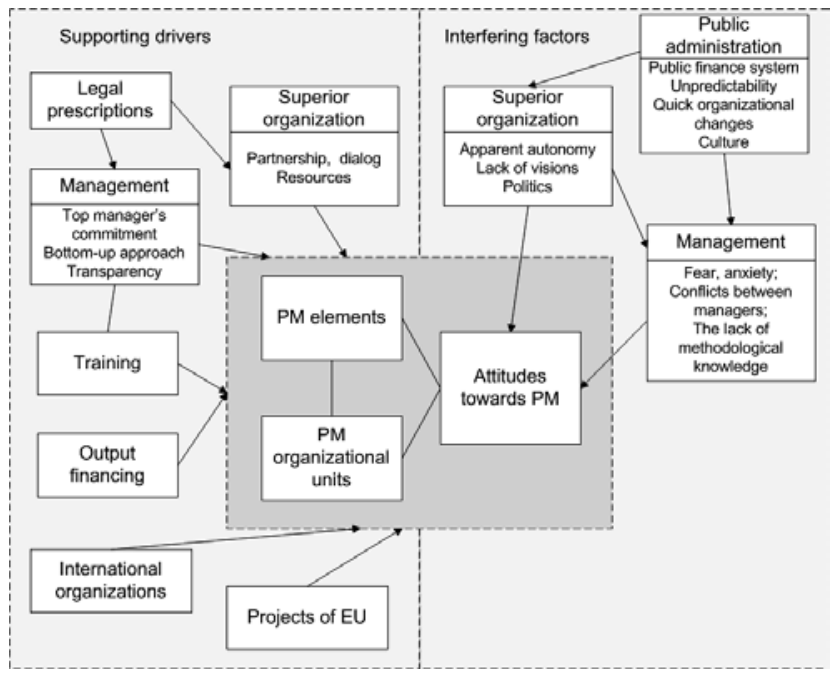

The examined phenomenon is located in the centre of the figure: PM elements and PM-related organizational units and positions. As a result of the study I have identified another central category: managerial attitudes towards PM, which are connected to PM elements and units applied. On the left and on the right of the figure the supporting and interfering factors affecting PM can be found.

During the process of analyzing the interviews, I identified some supporting and hindering mechanisms. It was interesting that during the coding certain categories appeared simultaneously as supporting and as interfering factors. These codes were 'management' and 'superior organization', and I had to create subcategories to better understand the phenomenon.

\section{Supporting factors}

A superior organization (ministry or state secretariat) will appear as a driver related to performance management when it treats the agency as a partner, provides additional resources for the introduction of PM tools (required by the superior organ), and there is a dialogue between the two levels.

"They [the secretary of state and head of the agency] developed the annual plan together.
Then there was a regular discussion about it. This type of negotiation does not exist today. " (I6)

An important subcategory of management is the top manager's commitment to PM application.

"If the head of the organization considered it important, you would move mountains. But if he or she did not consider PM important, it would become a struggle." (I6)

"In the case of proactivity and interest of the top manager PM can work quite well. If commitment existed, the head would find external sources, consultants, his/her own pattern, etc." (I5)

The personal commitment of the heads of the agencies is obviously one of the key supporting factors, however it could not have a long-term effect in the period of this study. An important finding of the web content analysis was the rapid change of the heads of the agencies, thus we can say that it is not a stable position in Hungarian agencies. Only 6 heads out of 75 were in their position before 2010 .

"The head of an agency is] the lowest level of politics. And I think nothing is worse than the lowest level of politics.” (I2)

Besides the heads, their deputies could have a crucial role in supporting PM tools, and a deputy position can be a stable and committed leader role. But this hypothesis requires further investigation.

Empowerment of employees has also a supporting role in the application of PM. Appearance of transparency as a management value influences some PM tools (e.g. use of websites, public performance report).

"The main goal of our performance report is to improve the international transparency and to gain credibility and trust towards our organization." (II)

Legal requirements could have a positive effect on PM applications (e.g. introduction of accrual accounting in Hungarian public organizations), but a regulation itself is not sufficient, because the introduction of PM systems requires knowledge, time, additional financial resources, etc. If supporting mechanisms were not prescribed by the regulation, organizations would introduce PM only formally, or they would simply not apply the required PM methods at all.

The role of trainings is twofold: it increases the PM-related knowledge and skills of managers, and the training of the staff has a positive effect on motivation. Another important factor is output financing which 
has contributed to the recognition of the role of performance management in the examined organizations.

\section{"The management control department compares cost data from time to time and if they see some- thing, then they try to solve it in order to generate more revenues." (I3)}

The methodological requirements of projects (co-) funded by the EU can contribute to the development of organizational performance management as well.

"In the EU projects we use Gantt charts for planning, we have to make benchmark analysis, there are indicators, these have to be reported quarterly, we have cash-flow plans..."(I6)

\section{Hindering factors}

In this subchapter I will overview the main factors hindering PM applications, based on the interviews. Some interviewees pointed out that legal and financial independence of the agency is often limited, their autonomy is apparent.

"Sometimes they treat us as a ministry department, and our institutional budget is handled by the controlling institution as if it were its own budget." (I6)

The lack of clear visions was perceived by some interviewees due to the frequent change of ministry staff (ministers, secretaries, other decision-makers).

"We have just established a new function and they want to take it away. And we started to build it without any additional financial resources, and now they want to take the function and also budget resources. Well, we said that we'll give back gladly all what the ministry has provided for this task. And they do not understand. Because the minister was changed as well." (I6)

"Due to the fact that people change frequently in the ministry, we have to teach them again and again what our duty is.”(I3)

Regarding the management of the agency conflicts between top-managers appeared as a hindering factor.

"Earlier I wanted to introduce ISO, but with the former top-management I could not do that." (II)

The lack of methodological knowledge regarding PM is also a hindering factor. According to the interviews many managers of the agencies do not dare to be proactive and they feel anxious.
"Change of attitudes is necessary. This highly centralized system provides a very small autonomy for agencies, and the fault-finding attitude and the complete lack of empowerment are not good. So it is very hard to act like a leader and difficult to achieve results." (I5)

The broader context of public administration is also an important category among hindering factors, it influences also the mechanisms described above. The Hungarian public finance system, the unpredictable and quick organizational changes and last but not least some cultural characteristics of public administration were the main subcategories.

"The most important value of public administration is stability, and it always goes in the direction of mediocrity. And therefore there is a constant struggle with efficiency and effectiveness." (I2)

In summary, the possibilities of PM in Hungarian agencies can be interpreted in a complex and less supporting context. The interviewees were selected from agencies that are considered performance oriented, and even in their case, often appeared to be skeptical and with a negative attitude towards PM. I have seen examples for successful implementation of PM tools, however in order to operate stable and integrated PM systems at organizational level, many factors of the recent context should be changed.

\section{Conclusions}

The first research question focuses on performance management tools appeared in Hungarian agencies. Based on the results of the web content analysis, the conclusion is that the examined elements of PM are not completely unknown in the majority of agency-type organizations, however I have found a very heterogeneous situation. 20 organizations (out of 75) did not publish any PM-related tools on their websites, while another 20 organizations published three or more different PM tools. It is important to keep in mind that this type of information on the websites do not give a full and accurate picture about PM-related organizational processes, I cannot draw well-grounded conclusions on the characteristics of the use and on organizational embeddedness. But the appearance of PM-related organizational units (e.g. departments) or positions in organizational structure indicate the institutionalization of performance management. The result of the analysis is similar: 40 per cent of the agencies did not apply any PM-related organizational units or positions, while in 22 cases (about 30 per cent) the 
organizational structure included two or three PM-related units or positions.

The second research question aimed at exploring the causes of this heterogeneous picture. I tried to identify the main factors, which influence PM applications. The qualitative research phase was based on semi-structured face-to-face interviews (Kvale, 2005) with some senior managers and one consultant. The analyzed performance management systems can be characterized by fragmentation: some elements do work well, but they are not integrated. I found only one organization where the organizational level methods and individual level tools were connected, in other cases the management cycles at strategic and operational level were disconnected.

During the analysis of the interviews a very complex context has evolved (see Figure 11). The role of management and the superior organ was twofold: many supporting and inhibitory mechanisms were identified within both categories. A superior organization can promote PM when the agency-type organizations are handled as partners, there is real dialogue between them and additional resources are provided for meeting the expectations related to PM. At the same time a superior organization could have a negative effect on performance management applications when only apparent autonomy is provided to agencies and the expectations are conflicting and changing rapidly.

The personal commitment of the head of an agency is clearly one of the most important influencing factors regarding PM, however this driver could not prevail. Based on the content analysis, the change of the heads of the agencies is relatively rapid, it is not a stable position in Hungary. In this situation the role of deputies can be an interesting question, but it requires further investigation. Transparency as a value and empowerment can contribute to the success of PM applications, however conflicts, both perceived and real, between managers and the lack of PM-related knowledge have a negative effect on PM.

During the research I found many laws or decrees which prescribe the application of specific PM tools in agencies. A law or decree alone is not sufficient for successful PM application, it requires professional knowledge, time and additional financial resources. Without any incentives the intention of legislation did not prevail: the organizations apply PM methods only formally or they do not apply it at all. The role and effects of legislation regarding PM are controversially judged by other researches as well (Cavalluzzo - Ittner, 2004; Julnes - Holzer, 2001).

Finally, I would like to outline some further research directions, which could enrich the understanding of this field. There is a question about the role of projects (co-)funded by EU in PM-related knowledge transfer. Examinating the barriers hindering the adaptation of existing knowledge could contribute to a deeper understanding of the function of public administration. Or a content analysis of agencies' performance reports could provide some insights into the measurement practices of Hungarian agencies.

\section{References}

Anthony, R.N. - Young, D. W. (2003): Management control in nonprofit organizations. New York: McGrawHill/Irwin

Bodnár, V. (2005): Teljesítménymenedzsment vagy controlling? in: Bakacsi Gy. - Balaton K. - Dobák M. (eds.): Változás és vezetés. Budapest: Aula: p. 147-153.

Bouckaert, G., - Halligan, J. (2008): Managing performance: International comparisons. London [u.a.]: Routledge

Boyne, G. A. (2003): Sources of Public Service Improvement: A Critical Review and Research Agenda. Journal of Public Administration Research and Theory, 13(3): p. 367-394. http://doi.org/10.1093/ jpart/mug027

Cavalluzzo, K. S. - Ittner, C. D. (2004): Implementing performance measurement innovations: evidence from government. Accounting, Organizations and Society, 29(3-4): p. 243-267. http://doi.org/10.1016/ S0361-3682(03)00013-8

Creswell, J. W. (2009): Research Design. Qualitative, Quantitative and Mixed Metods Approaches. Thousand Oaks: Sage Publications

Creswell, J. W. - Plano Clark, V. L. (2011): Designing and conducting mixed methods research (2nd ed). Los Angeles: SAGE Publications

de Bruijn, H. (2002): Managing performance in the public sector. London and New York: Routledge

Esse, B. (2012): Elmés döntések. Heurisztikus folyamatok a beszállítóválasztási döntésekben. Budapest: Budapesti Corvinus Egyetem, Budapest. Retrieved from DOI 10.14267/phd.2013026

Glaser, B. G. - Strauss, A. L. (1967): The discovery of grounded theory: strategies for qualitative research (4. paperback printing). Chicago: Aldine

Hajnal, G. (2010): Agencies in Hungary: Uses and misuses of a concept. in: P. Laegreid - K. Verhoest (eds.): Governance of public sector organizations. Autonomy, control and performance. Houndmills / New York: Palgrave Macmillan

Hajnal, G. (2011): Agencies and the Politics of Agencification in Hungary. Transylvanian Review of Administrative Sciences, 7(special issue): p. 74-92.

Hajnal, G. (2012): Hungary. in: K. Verhoest - S. Van 
Thiel - G. Bouckaert - P. Laegreid (eds.): Government agencies. Practices and lessons from 30 countries. Palgrave Macmillan

Hood, C. (2006): Gaming in Targetworld: The Targets Approach to Managing British Public Services. Public Administration Review, 66(4): p. 515-521. http:// doi.org/10.1111/j.1540-6210.2006.00612.x

Julnes, P. de L. - Holzer, M. (2001): Promoting the Utilization of Performance Measures in Public Organizations: An Empirical Study of Factors Affecting Adoption and Implementation. Public Administration Review, 61(6): p. 693-708. http://doi. org/10.1111/0033-3352.00140

Kassó, Z. (2006): Miért van szükség az államháztartás pénzügyi beszámolórendszerének megváltoztatására? in: A. Vigvári (ed.): Decentralizáció, transzparencia, elszámoltathatóság. Budapest: Magyar Közigazgatási Intézet: p. 83-130.

Király, G. - Dén-Nagy, I. - Géring, Z. - Nagy, B. (2014): Kevert módszertani megközelítések. Elméleti és módszertani alapok. Kultúra és Közösség, 2014(2)

Krippendorff, $K$. (2004): Content analysis: an introduction to its methodology (2nd Edition). Thousand Oaks; London: SAGE

Kvale, S. (2005): Az interjú. Bevezetés a kvalitatív kutatás interjútechnikáiba. Budapest: Jószöveg Múhely Kiadó

Lórincz, L. (2005): A közigazgatás alapintézményei. Budapest: HVG-ORAC

Mitev, A. Z. (2012): Grounded theory, a kvalitatív kutatás klasszikus mérföldköve. Vezetéstudomány, 43(1): p. 17-30.

Mol, N. P., - de Kruijf, J. A. M. (2004): Performance Management in Dutch Central Government. International Review of Administrative Sciences, 70(1): p. 33-50. http://doi.org/10.1177/0020852304041229

Moynihan, D. P. - Pandey, S. K. (2005): Testing how management matters in an era of government of performance management. Journal of Public Administration Research and Theory, 15(3): p. 421-439.

$O E C D$ (2002): Distributed public governance - Agencies, authorities and other government bodies. Paris: OECD

Pollitt, C. - Bouckaert, G. (2011): Public management reform: a comparative analysis: new public manage- ment, governance, and the neo-Weberian state (3rd ed). Oxford ; New York: Oxford University Press

Pollitt, C. - Talbot, C. (2004): Unbundled government. London: Routledge

Strauss, A. L. - Corbin, J. M. (1998): Basics of qualitative research: techniques and procedures for developing grounded theory (2nd ed). Thousand Oaks: Sage Publications

Takács, E. (2015): A közszolgálati szervezetek értékelési módszereinek osztályozása. Vezetéstudomány, 46(3): p. 45-56.

Van Dooren, W. (2005). What makes organisations measures? Hypothesis on the causes and conditions for performance measurement. Financial Accountability - Management, 21(3): p. 363.

Van Dooren, W. (2006): Performance measurement in the Flemish public sector: A supply and demand approach. Katholieke Universiteit Leuven, Faculty of Social Sciences, Public Management Institute, Leuven. Retrieved from http://www.kuleuven. ac.be/doctoraatsverdediging/cm/3H05/3H050238. htm

Van Dooren, W. - Bouckaert, G. - Halligan, J. (2010): Performance management in the public sector (Second edition). Milton Park, Abingdon, Oxon ; New York, NY: Routledge

Van Dooren, W. - Lonti, Z. - Sterck, M. - Bouckaert, $G$. (2007): Institutional drivers of efficiency in the public sector. Paris: OECD Public Governance Committee

Van Helden, G. J. - Johnsen, A. - Vakkuri, J. (2007): Understanding public sector performance management: the life cycle approach. In Conference of the European Group of Public Administration (EGPA) 'Comparing performance' 19-22 September, 2007.

Verhoest, K. - Van Thiel, S. - Bouckaert, G. - Laegre$i d, P$. (eds.) (2012): Government agencies: practices and lessons from 30 countries. London: Palgrave Macmillan

Wettenhall, $R$. (2005): Agencies and non-departmental public bodies: The hard and soft lenses of agencification theory. Public Management Review, 7(4): p. 615-635. http://doi. org/10.1080/14719030500362827 